\title{
Supporting Young Adolescent Students in Reading
}

\author{
Jo Fletcher \\ College of Education, University of Canterbury
}

\begin{abstract}
This paper addresses better understandings of the wider systemic factors that support 11- to 13year-old students in reading. A socio-constructivist paradigm was used to view multiple constructions of realities. Using a socially constructed ontology a mainly qualitative approach was instigated. From two case study New Zealand schools the principals, literacy-leaders, teachers, parents and students were interviewed. Additionally, a structured observation schedule was used to observe the teachers during a guided reading lesson. This study has shown that teachers and the schools they are situated within are only one part of the support network for 11- to 13year-old students. I maintain that although this part is important, teachers solely cannot be either congratulated or blamed for the reading outcomes of students. Rather the responsibility is shared amongst those in leadership roles in schools, the parents, the local community, external agencies such as the ministry of education and the wider socio-cultural community.
\end{abstract}

\section{Introduction}

When a student reaches the early years of adolescence in their schooling there is an expectation that they will have effective skills in reading and comprehending a range of text types. However, both within New Zealand, and internationally, this is not the reality for a growing number of students $[1,2]$. Nevertheless, there is an expectation that, on entering secondary school, students should have solidlygrounded reading skills and strategies which allow them to engage in and comprehend a wide range of text types. Students who have low levels of reading literacy find that this impacts on most other subject areas [2]. This in turn can lead to a spiral of failure, disengagement with schooling, lowering of selfesteem, long-term educational and life aspirations and outcomes [3, 4]. Another impact on successfully engaging in learning is the need for strong literacy skills in today's globalised and information age society [5]. More employment positions require higher reading and writing literacy skills than previously. The fast pace growth in the use of information communication technologies (ICT) such as emails, accessing web-pages, instant messaging, pod-casting and chat forums to effectively communicate have placed even greater demand on literacy skills. Whether used in the classroom, for study, employment or recreation, these technologies require reading and writing proficiency that differs in some respects from that needed for print media [6].

In New Zealand, primary schools take children from five years old up to 13 years of age. This differs, for example, from the United Kingdom where primary schooling only includes children up to11 years of age. I contend that the transition from primary to secondary school can make an impact on the reading achievement of students. New Zealand children who continue in primary schools until 12 to 13 years of age may have distinct advantages as they are situated in these final years of primary schooling with teachers who view teaching reading as their business. I suggest in countries such as those in the United Kingdom, that teachers in secondary schools may well assume that children can already read when they arrive at 11 years of age. This is often the case in our New Zealand secondary schools where children begin at approximately 13 years of age. Furthermore, in secondary schools, often any specific teaching of reading is likely to be seen as 'remedial' and may only be offered when it is clear that the child is having problems understanding what is being taught in various subjects.

Teachers of young adolescent students are only one agency that influences their attitudes to and success in reading. Principals, literacy leaders, parents and the effectiveness of home -school relationships are all important components in developing a nurturing and effective literacy learning environment. As Bronfenbrenner [7] suggested, over time, there are constant interactions between individuals and their environments and all play a part in influencing learners. He referred to environmental influences as significant others arguing that their importance, relative to the developing child, lies in the belief systems inherent in them and in how those systems interact with that child/student. For example, the interactions and relationships children have with their surroundings, inclusive of family, school and neighbourhood, wield a positive or negative influence on the children's cognitive and emotional development. Not surprisingly, poor or non-existent relationships between these systems bring little advantage to children [8]. With these premises in mind, when principals and teachers strengthen their relationships with students' homes and when parents and caregivers strengthen their relationships with their children's schools, the children are likely to be 
advantaged. In a similar manner, Weigel, Martin and Bennett [9] in their study of the ecological influences on the literacy skills of children, highlight the importance of appreciating the numerous contexts that can influence reading achievement. Taking cognizance of these commentators, I wanted to comprehend how the variety of groups of people, such as teachers, literacy leaders, principals and parents, can work together in a systemic manner to provide positive and effective literacy learning environments for students in their final two years of primary schooling. Therefore, this research article explores the wider systemic conditions that support reading for 11to 13-year-old students. It aims to better understand the interrelationships of people from different groups that contribute to supporting students in their final two years of primary schooling.

\section{Literature}

In New Zealand schools, the focus - as evident in the National Administration Guidelines (NAGS) continues to be to improve the achievement of all students in literacy situated across a range of socioeconomic areas [10]. Although schools in low socio-economic areas are often targeted both by New Zealand Ministry of Education initiatives and research investigations [11, 12] the wider systemic factors influencing supporting the reading achievement of students in all schools also needs to be better understood. This is particularly so for our young adolescent students where research investigations have indicated some concerning trends which might influence outcomes in reading development for this age group.

For example, in the second cycle of the Progress in International Reading Literacy Study (PIRLS) 2005/6, New Zealand, comparative to other higher performing countries, had a notable sized group of 10 year-old students who were poor readers and who did not reach the PIRLS lower international benchmarks [13]. This pattern of underachievement by a considerable percentage of students in reading has remained stable over the last several years. It is of continuing concern that in reading, the lowest performing 20 per cent of New Zealand students are two years behind the average reading age of their peers [1].

Another pattern of achievement, both in New Zealand and internationally, has been a reported plateauing or tapering off in students' progress in reading achievement as they reach their middle school years [14, 15]. In New Zealand, Hattie [15] when establishing the norm for approximately 92,000 students from a wide range of school types, deciles and ethnicities on Assessment Tools for Teaching and Learning (asTTle)1, [16] items in reading, found that the average performance across the year levels showed that there was a flattening off in reading once students reached the upper primary years. At Year 5 (approximately nine years of age), over $80 \%$ of the students were at or above expectation, however at Year 8 (approximately twelve years of age), just under 50 per cent were below expectation.

In the US, commentators $[14,2]$ have reported a slump in reading achievement at the fourth grade, when a child is approximately eight to nine years of age. Hattie [15] suggests that the 'fourth grade slump' in the US is different to the New Zealand pattern, where instead of a slump there is a plateau in achievement during the final three to four years of the upper primary schooling (Years 5 to 8). Nevertheless, both in New Zealand and the US, students in low socio-economic schools and/or from low-income families tend to be more likely to exhibit signs of tapering off in their reading $[16,17]$. Furthermore in the New Zealand study by McNaughton, Lai, MacDonald and Farry [17] they found that despite successful interventions at an earlier age level, for a significant number of students in low socio-economic schools there was still a tapering off in reading achievement. Additionally, in New Zealand both Māori (the indigenous people of New Zealand) and Pasifika students are more likely to be underachieving in reading [13]. Pasifika is a term of convenience used to encompass a diverse range of peoples from the South Pacific region now living in New Zealand, who have strong family and cultural connections to their Pacific Island countries of origin.

Considering the issues raised within recent literature, it seemed timely to investigate what are the wider systemic components that effectively support reading for young adolescent students. In doing so, I sought to uncover how the different groups of people interrelate and connect to support young adolescent readers.

\section{Method}

The two main types of schooling within New Zealand, state schooling and integrated state schooling, were purposively selected. Both types of schooling are fully funded by the government. State integrated schools were previously private schools, (often Roman Catholic in denomination) which have been integrated into the state system but still safeguard and maintain the special character of the education they have provided.

Four different types of measure were used to identify effective teachers of reading for students in their final two years of primary schooling. Firstly, the two schools had been nominated by a research project advisory team with expertise in literacy. The advisory

\footnotetext{
1 asTTle is an educational resource for assessing literacy achievement in both reading and writing.
} 
team members considered that these two schools had effective teachers of reading for 11- to 13-year-old students. Next, the two case study principals nominated Year 7 and 8 teachers who they perceived to be effective in teaching reading. Furthermore, the reading results from the assessment criteria of the different standardised testing by the schools, showed overall improvement in students' reading levels and/or stanines in relation to their chronological ages over a one-year period, or positive achievement in comparison to the achievement of students from similar school types. This improvement in reading levels was over and above the expected incremental gains students would make as they progress through their years of schooling. Finally, the positive commentary in the most recent Education Review Office (ERO) reports on the two schools (available on the New Zealand Ministry of Education website http://www.ero.govt.nz/ero/reppub.nsf/) supported these findings. ERO is part of the government's strategy in reviewing school performance and providing a form of accountability.

\subsection{The case study schools}

Westbury School (pseudonym) is situated in a town in the South Island of New Zealand. Westbury is a state, full primary school which comprises of students from years 1 to 8 . At the time of the study there were 407 students at the school. The students were mainly from New Zealand European descent, with 12 per cent Māori. The school comprised of students from a range of socio-economic status (SES) backgrounds - from unemployed parents or those on low wages, to those who owned small businesses or who were from a professional background. Coal mining and farming were two key providers of employment in the wider school's community, with supporting services providing much of the other local employment. The principal of the school was female and had been the principal of the school for one year. She had previously been the deputy principal of the school for ten years.

Longmuir School (pseudonym) is an integrated state school in a city in the South Island of New Zealand. The students were mostly from New Zealand European descent. The school was in a high socioeconomic area. The parents and children mainly came from the associated Roman Catholic community. Overall, most parents were employed locally within the agricultural, forestry, horticultural and seafood sectors or in a variety of career paths within the city. The principal was male and had been at the school for one year and had previously held a position as a principal. Prior to him becoming the principal, the literacy leader had the role of acting principal.

\subsection{Collecting the data}

Two teachers were selected at both schools by their respective principals as effective teachers of reading. In addition to interviewing the teachers, the school literacy leaders, the school principals, four parents of Years 7 and 8 students of differing reading abilities, and twelve Years 7 and 8 students representing a range of reading abilities were interviewed. The semi-structured interview questions and procedures were trailed at a pilot study intermediate school. Apart from the students who were interviewed in focus groups of three at their respective schools, the other participants were interviewed individually. Questions from the interview schedule were used as a guide to structure the interview but did not limit discussions to a predetermined agenda. The interviews each took approximately 45 minutes to complete and were audio-taped and later transcribed. Also, the four teachers were observed teaching instructional reading.

\subsection{Analysis of data}

First, themes were identified as initial coding categories. Next, using open coding the themes were used to help analyze and segment the data in the recorded transcripts. These themes included the relationships between the teachers and parents, the use of libraries, the role of the principal in the overall organization of staff and professional development and the influence of external reviews of the school.

After that, a second order of analysis of the interview transcripts was carried out, using axial coding. Links between concepts and themes were identified such as the relationship between principal's expectations of their teachers and the relationships the teachers developed with their students. In the final process of analyses, selective coding was used to uncover the major concepts that recurred frequently [18]. The focal point was to differentiate the higher order significant ideas and categorize them more precisely.

\section{Findings and discussion}

The four main concepts that arose from the analyses of the data suggest that there are numerous interrelationships that can support reading for young adolescent students. These included the external interrelationships with the school, such as reviews of the school by the Education Review Office (ERO), and staff involvement in research and advanced study; the internal inter-relationships amongst school staff; the development of effective home-school 
relationships; and the relationships amongst the wider community and the school.

\subsection{External influences}

The principal at Westbury School discussed how there was about to be an upcoming visit by the ERO. She explained that partly because of this there had been a continued strong focus on literacy and numeracy, rather than other curriculum areas. She said:

Well, our school has an emphasis on literacy and numeracy, so other things go out the window I am afraid, and ERO is coming in six weeks, so of course, I am not going to say that, but it (literacy and numeracy) is a priority.

In New Zealand, there has been a priority on students' achievement in literacy and mathematics in government policies. This is evident in the National Administration Guidelines (NAGs) which focus on the requirement that New Zealand schools prioritize student achievement in literacy and numeracy (Ministry of Education, 2009).

Longmuir School had been reviewed by ERO prior to the arrival of the new principal. The ERO report had indicated that there was a need to improve reading achievement. Taking this report into account, the school staff was involved in ongoing literacy professional development with a literacy advisor. The centre of attention was assessing for learning in order to improve both the quality of the teaching and learning. The focus was to use assessment information to identify needs. However, at the same time there was a commitment to provide assessment information to assure parents and the public about the quality of the education. The principal said:

The ERO report said that reading needed a lot of work on it and so the question I asked when I came was, 'Why didn't you use it as a target in your Assess to Learn work? Why wasn't that where you were focused?' They said that the answer to that seemed to be that, the testing that they have done was suggesting that the reading was very good and that the writing in comparison was quite significantly poor. So, that is where they were going to look. Their thinking was that if we raise the writing ability then reading is going to go up with it anyway.

The principal demonstrated how he was working alongside the teachers and literacy leader, raising questions associated with the feedback from the ERO report and beginning to evolve a whole school plan. At both schools it was apparent that the government strategy in reviewing schools was a positive catalyst for the principals and their staff to focus on improving literacy achievement for their students.

\subsection{Advanced study and research}

Teaching is a life-long learning career. Educators who undertake research and engage in post graduate study are able to connect recent research findings to their practices in teaching and engaging young adolescent learners. The principal at Longmuir School, recognizing the value of research, had used the skills and knowledge of one of the Year 7 to 8 teachers. She had undertaken research study in information communication technology (ICT) and how it might motivate literacy learning. The principal selected the teacher to lead the first Year 7 and 8 class to have the suite of ICT equipment. When Teacher 4 was asked if and how the ICT was supporting the 11-to-13 year-old students' reading, she responded:

Amazing - their engagement particularly. I have done heaps of research into it and it is not proven to improve their achievement as such. I am a believer of the benefits of ICT, if it is encouraging them to be more focused. Well, in the long run that is going to improve their achievement, because how could you say that it is not - if a child who is not going to be focused ...they are not going to complete the tasks...It makes the management of a time like that really easy because I don't have interruptions.

Also, at Westbury School several staff members who had been involved in post graduate study. The principal of the school had undertaken post graduate study in reading to become a reading recovery teacher earlier in her career. Both of the Year 7 to 8 teachers had also undertaken post graduate study recently. One teacher had completed her Masters thesis in gifted and talented education. The principal, aware of this teacher's strengths used it to the advantage of the students in her school. She said:

Last year, Karen (pseudonym), actually had a large group of $\mathrm{G}$ and $\mathrm{T}$ (gifted and talented) kids. She actually did her thesis at university on $\mathrm{G}$ and $\mathrm{T}$ kids and she caters for those children. They are mainstreamed but they do come out for extension and things. We keep our $\mathrm{G}$ and $\mathrm{T}$ kids in clusters, groups together of like-minded kids and she has them, she caters for them. With gifted and talented children come some quite high maintenance parents. When they are in Karen's room the parents are quite happy because she does extend and push them.

Additionally, the other Year 7 and 8 teacher at Westbury School had undertaken postgraduate study in children's literature. He not only articulated his philosophic beliefs of engaging his students in discourse and encouraging them to voice their perceptions about text, but it was demonstrated in the classroom observation of his guided reading lessons. 
He provided a collaborative learning environment where the students engaged in debate and discussion about texts and authors.

As well as these three staff members having undertaken post graduate study, the whole school had been involved in a research project led by a North Island research institute. The research was funded by the West Coast Development Trust to support literacy achievement. The local community trust decided to invest in their upcoming generation of students and sought an expert research leader in literacy development to lead this study. The wider sociocultural context had fed into several schools within their community to have focused professional development that was underpinned with research based data.

The principal described the benefits of her school being part of the research-based professional development.

We had our big report the other day that will go to the development trust because they put the money in. At the end we listened and it is all figures and things and Simon (pseudonym for the professor leading the research project) said teachers on the West Coast are better than most teachers in New Zealand as far as literacy levels go. So that was just a real pat on the back for us, because we (schools in a region) went through the terrible ERO report (previously).

The community development trust had provided funding to initiate research and professional development. And, as discussed earlier, similar to Longmuir School a prior ERO report had now focused the school's staff on raising reading achievement.

\subsection{Internal relationships within the school}

An instance of how interrelationships within the school context had a flow through effect for the teachers was shown in the interactions between the literacy leader and the teachers. The literacy leader at Longmuir School explained how she had worked with other teachers with the assessment data to improve teaching strategies.

I actually introduced the at-risk monitoring monthly plan and it was like we needed to move them (the teachers) from monitoring to, 'Why are we monitoring? What are we doing with that information and how is that affecting our teaching? How is that making us change what we are doing to get better improvement?'

The literacy leader was interacting with the teachers to provoke their thinking about using assessment data to benefit and guide future teaching and learning.

At Westbury School, a school-wide strategy was in place to improve reading outcomes for the Māori students. The principal, who had been a specialist teacher in reading, explained:

For a start, we as a staff, we looked at our Māori students and we identified the stanine threes and fours. The kids that you can move and they were mainly in syndicates two and three, so we put extra teacher aides in there to work in the classrooms during reading times.

The teachers and principal had used assessment data to identify students needing extra support in reading, and employed teacher aides to give additional reading support to these low achieving readers.

Another instance of the teachers and literacy leader working together alongside the literacy advisor was outlined by the literacy leader. She said:

When I came here four years ago, it was very much you did your job and you stayed in your own room and it was really competitive too. Not that, that is bad but it can become a little bit unhealthy. There wasn't a lot of sharing. Now, with the PD you have to share. You have to share what you are doing. You have to share your successes. You actually have to talk about them.

Within a school context the roles of individuals can change or include dual roles. Teacher 3 was also the literacy leader at Longmuir School and as described earlier, had been the acting principal prior to the appointment of the current principal. In her different roles her personal experiences influenced how she instigated processes. The changes that she made influenced the culture of the whole school environment. She said:

We (the teachers) have critical friends and we are buddied with them and we have to set goals together and then they (literacy professional development advisors) come in and look at that goal and it is always a literacy focused goal. It works really well, because it had been hierarchical. Management came in and did your appraisal ....It was horrible. I had to do it and I hated going in to do it, and so last year when I was acting principal I changed it, because I knew what it was like.

In this case the negative experiences of a hierarchical appraisal process had led the literacy leader, when in the role of acting principal to improve the school culture by developing a more collaborative and supportive approach amongst the school staff.

\subsection{Home-school relationships}

One of the parents of a low progress reader voiced her dissatisfaction with the relationship she had had with the prior principal and previous teachers at Westbury School. Her pleas in past years for extra help for her son had in her opinion not been listened to and understood. She explained: 
I have asked for help for help for Kelvin with his reading right from probably year two or three and I am always told that Kelvin is not bad enough to have help. They need to be reading more than two years of their chronological age and Kelvin's never...I mean he only misses by a hare's breath and I am always told that here are worse in the class than Kelvin. He has three years in a row been assessed by the reading resource lady...but there has never been enough funding to have help for Kelvin. Until last year when I got hold of Maggie (the newly appointed principal) and I came up with Kelvin's reports and I stressed that I was very concerned because if he can't read, it is not just his reading it affects everything... What I do find unfortunately with some of the teachers is that they wait until the end of the year to tell me (that he is achieving below average).

The relationship between the home and the school had been strengthened once the principal acknowledged that Kelvin needed additional support.

Another example of how home-school relationships at Westbury School influence reading development was a mother whose year 7 daughter was in Teacher 1's class and was achieving well in reading. The mother was positive about what was happening at the school. She was appreciative of the support Teacher 2 had given her sons even though they were not in his class. She explained.

We have also got a very good friend who is a teacher here - Mark (pseudonym for Teacher 2) and he gets the books. Especially, when we first moved here the boys weren't much into reading. Well, he has got them into reading. He sources books for them and Cathy (my daughter) as well. So, we are quite lucky really.

This gives evidence of one teacher, reaching out to help and support students in the wider school context. The flow effect from teacher to student in this instance was also evident in the teacher's and students' other roles of family friends within the wider.

The relationship between the home and school plays an important part in providing support for young adolescents' reading. At Longmuir School, one of the parents described the type of interactions she had with her child's teacher. She said:

Well, the teachers are pretty good at giving you feedback. That is basically how I know. Also, too by what they bring home in their homework. They (the teachers) actually sit down and discuss those (assessment results) with you and they tell you where your child falls and where the average child will fall according to that age and what is expected. There is always a variation - some are always a lot better and some are a little behind. This is where they can slip through the gaps as well. I must admit I don't know anything about the curriculum side of reading here. My parent help hasn't extended to the classroom. I tried to get into a classroom and I lasted half a day and I came out with a whopping headache. Teaching is not my area.

Another parent of a child at Longmuir School described how she kept in daily contact with her daughter's teacher about reading progress which had been of some concern.

I don't live far away and I have been quizzing her (the teacher). She (the teacher) has just got her on to a couple of books and an author she has really enjoyed. We walk to school, it takes about 10 minutes and every day I get an update. We sit and talk.

At this school there was evidence that there were a strong links between the home and the school, some initiated by the teachers and other links developed by the parents, as in the case of the parent who was getting a daily update of her daughter's reading progress from the teacher in an informal manner.

\subsection{Relationships with the local community}

Although common links were identified across both the case study schools there were points of difference. The special character of Longmuir School as a Roman Catholic integrated state school meant there were strong interrelationships amongst the home, church and school. An example of the interflow between the church context and the school context was the funding of ICT to support literacy and motivation to learn. The leadership team of the church worked together by providing a funding grant to support reading and learning of the year 7 and 8 students. The principal explained:

Well basically, we had to do a lot of consultation with the parents because ...we were looking at user-pays to start with... They (the community) felt, particularly with our Catholic character, that if we were going to do something like that, if we were going to do it, it should be across the whole school for everybody. It should be available for everybody (at all year levels). The local church group came up with a grant. We got about $\$ 11,000$ from them so we have been able to keep the cost down to $\$ 50$ a term (per pupil in the ICT classes). That is for everybody in year 7 and 8...They have Apple laptops - one between two. There are 16 to a class. There is an interactive whiteboard they have in the class with data projector and digital cameras.

One of the students interviewed provided an example of how this initiative by the church, along with the home and school components had a flow-on effect into motivating him to read and write using ICT. The student said: 
I don't like the writing, because I am not that good at it. It is probably one of the boring things ... but the podcasts are cool.

In this case, there had been a change to the affective conditions impacting on writing and reading as a meaning construction process. The reluctant literacy learner had been motivated to read and write using podcasting which he viewed as 'cool' as a way to express his ideas.

For this student's teacher the introduction of more extensive information communication technologies in the classroom meant that there could be changes to pedagogical practices.

When I first started with this class at the start of the year I didn't have the interactive whiteboard and I felt I was doing a lot of talking, a lot of reexplaining all that sort of thing. The other thing is that for the kids it is very visual, it is very interactive. They actually feel by, I guess, touching the screen that they are choosing the activity, they have more ownership. It is more of a physical, sort of like, I am selecting that one to do and reading up now on it.

Following on from this example of the ICT class, the students had been given the opportunity to write letters to the principal to argue why their class should get the new pod of laptops that was soon to arrive at the school. The principal explained:

The two classes have been having a debate about who gets the new ones (computers) you see. The Year seven's argument is that they have the skills and expertise now because they have been doing it for a term and a bit and so they should get the new ones. The Year eights are saying we have missed out for a term so we should get them. They are having a right old to and fro about it. We are doing argument writing so we are kind of encouraging it. Jacqui (literacy leader and Teacher 4) said, 'Write letters - you are doing argument writing. This is a good opportunity for you.' So they all wrote letters to me.

The students were able to voice their opinions to their principal on an issue that would personally affect them. This type of two-way dialogue between the students and their principal was also a way to practice and improve their written literacy skills. Clearly, the school community at this Roman Catholic integrated school had been cognizant of the critical need for their upcoming generation of learners to be able to use new technologies to communicate, learn and engage in literacy learning. Focused funding provided by the wider church community was providing a positive environmental influence to advantage students.

\subsection{Library access and use}

Westbury School, like most New Zealand schools, it had its own library. However the point of difference was that the children were able to access their school library during the school holidays which is not common practice in most primary schools. The principal explained:

The library at our school is the centre of literacy.

We have this fabulous library, which is open in the holidays. We have it open at lunchtimes. We pour a lot of money into it. It has a huge budget.

She went onto explain how there was dissatisfaction with the local community library. The students said that we have better selections here than they do at the town library. For this reason the school library started opening in the holidays. The principal had adapted the conditions for the students by opening the school library during the holiday periods to balance the lack of motivating resources at the town library. She was aware of the affective conditions which influence reader's decision to read, such as access to high interest texts which motivate readers. The students' views had been listened to and action had been put in place by the principal to enhance ready access to quality texts.

\section{Conclusion}

This study focused on how different groups of people interrelate amongst each other to support reading for young adolescent students. These groups of people have roles/ involvement within the school, the home, external agencies that support schooling, post graduate study and research, and the wider local community. All of these components interrelate providing dynamic and complex layers of support for 11-to-13 year old students. Nevertheless, what needs to be kept in mind is that certain features of effective practices and interrelationships that support literacy learning may be common within schools, but undoubtedly each school builds and adapts practices. These adaptations are influenced by each school's own unique circumstances within their wider sociocultural context. This was evident at Westbury School where the principal had let students have access to the school library during holiday breaks, as the local community library was perceived by her students as not having interesting books. Also, at Longmuir School, the church community had provided additional funding for ICT which had enriched the literacy learning environment. The members of the church community, similar to commentators such as Leu, Kinzer, Corio and Cammack [6] recognized that it was essential to prepare children for the new ICT literacies as they are central to the acquisition of knowledge and understandings in learning in today's world. 
The evidence from these case studies tends to suggest that along with school-wide professional development, the pursuit of advanced study, may allow a stronger knowledge of and understanding in a range of research-based effective teaching and leadership practices. This in turn may influence the individual and their teaching colleagues and, ultimately, outcomes for students. In this regard, I would like to see further research that investigates the relationships between effective teaching of reading and advanced study in literacy.

This study has shown that teachers and the schools they are situated within are only one part of the support network for 11- to 13-year-old students. I maintain that although this part is important, teachers solely cannot be either congratulated or blamed for the reading outcomes of students. Rather the responsibility is shared amongst those in leadership roles in schools, the parents, the local community, external agencies such as the ministry of education and the wider socio-cultural community.

I contend that reading and support for learning to read are positioned in the wider context of society. As Gee [19] argued from a socio-cognitive perspective, viewing reading from the position of merely psycholinguistic processing of skills shows a narrow understanding of how reading is embodied in the social world. He concluded that "a broad perspective on reading is essential if we are to speak on issues of access and equity in schools" (p. 116). As I consider what supports reading development, I suggest that by understanding the wider systemic environments that surround learning to read, a 'big picture' view of the interrelationships and dynamic nature of these contexts allows us to comprehend reading development from a more holistic perspective.

\section{References}

[1] Chamberlain, M. (2008) 'PIRLS 2006/2006 in New Zealand: An Overview of National Findings from the second Cycle of the Progress in International Literacy Study',

http://www.educationcounts.govt.nz/publications/series/25 39/pirls_0506/34905/7

[2] RAND Reading Study Group. (2002) Reading for Understanding: Toward a Research and Development Program in Reading Comprehension, RAND Education, Santa Monica.

[3] Chharbra, V. and McCardle, P. (2004) Contributions to Evidence-Based Research. In V. Chharbra and P. McCardle (Eds.) The Voice of Evidence in Reading Research. (pp. 3-13), Brookes, Baltimore.

[4] Stitch, T. (2001) 'Reforming Adult Literacy Education: Transforming Local Programs into National Systems in Canada, the United Kingdom and the United States', http://www.nald.ca/FULLLTEXT/stitch/reformin/cover.ht $\mathrm{m}$
[5] Overton, L., Hills, H. and Dixon, G. (2007) 'Towards Maturity: Looking at the Impact of E-Learning in the Workplace', http://www.e-skills.com/Work-based-elearning/1411

[6] Leu, D. J., Kinzer, C. K., Corio, J. L. and Cammack, D. W. (2004) Toward a Theory of New Literacies Emerging From the Internet and Other Information and Communication Technologies. In R. Ruddell and N. Unrau (Eds.) Theoretical Models and Processes of Reading $\left(5^{\text {th }}\right.$ ed., pp1570-1613), International Reading Association, Newark, DE.

[7] Brofenbrenner, U. (1996) Developmental Ecology Through Space and Time: A Future Perspective. In P. Moen, G. Elder and K. Luscher (Eds.) Examining Lives in Context: Perspectives on the Ecology of Human Development, American Psychological Association, Washington DC.

[8] Bronfenbrenner, U. (1979) The Ecology of Human Development, Harvard University Press, Cambridge MA.

[9] Weigel, D. J., Martin, S. S. and Bennett, K. K. (2005) 'Ecological Influences of the Home and the Child-care Center on Preschool Children's Literacy Development', Reading Research Quarterly (40,2), pp. 204-233.

[10] New Zealand Ministry of Education (2009) 'The National Administration Guidelines (NAGS)', http://www.minedu.govt.nz/educationSectors/Scholls/Polic yAndStrategy/PlanningReportingRelevantLegislationNEG SAndNAGS/TheNationalAdministrationGuidelinesNAGs. aspx

[11] Lai, M. K., McNaughton, S., Amituanai-Toloa, M., Turner, R. and Hsiao, S. (2009) 'Sustained Acceleration of Achievement in Reading Comprehension: The New Zealand Experience', Reading Research Quarterly $(44,1)$, pp. 30-56.

[12] McNaughton, S., Amituanai-Toloa, M. and Lai, M. K. (2007) Drawing Implications for the Literacy Strategy from Two Schooling Improvement Projects, Auckland Uniservices Limited, Auckland.

[13] Chamberlain, M. (2007) 'Reading Literacy in New Zealand: An Overview of New Zealand's Results from the Progress in International Literacy Study (PIRLS) 2005/2006',

http://www.educationcounts.govt.nz/publications/series/25 39/pirls_0506/34905/15

[14] Brozo, W. (2005) 'Avoiding the Fourth-Grade Slump', Thinking Classroom (6,4), pp. 48.

[15] Hattie, J. (2007) 'The Status of Reading in New Zealand Schools: The Upper Primary Plateau Problem (UP)', Reading Forum N. Z. (22,3), pp. 25-39.

[16] Chall, J. S. and Jacobs, V. A. (2003) 'Poor Children's Fourth-Grade Slump', American Educator (27,1), p. 14.

[17] McNaughton, S., Lai, M. K., Macdonald, S. and Farry, S. (2004) 'Designing More Effective Teaching of Comprehension in Culturally and Linguistically Diverse 
Classrooms in New Zealand', Australian Journal of Language and Literacy (27, 3), pp. 184-197.

[18] Charmaz, K. (2003) Grounded Theory: Objectivist and Constructivist Methods. In N. K. Denzin and Y. Lincoln (Eds.) Strategies of Qualitative Inquiry ( $2^{\text {nd }}$ ed., pp. 249-291) Sage, Thousand Oaks.

[19] Gee, J. P. (2004) Reading as Situated Language: A Sociocognitive Perspective. In R. Ruddell and N. Unrau (Eds.), Theoretical Models and Processes of Reading $\left(5^{\text {th }}\right.$ ed., pp. 116-132) International Reading Association, Newark DE. 